\title{
Antimicrobial and Herbal Drug Resistance in Enteric Bacteria Isolated from Faecal Droppings of Common House Lizard/Gecko (Hemidactylus frenatus)
}

\author{
Bhoj R. Singh, ${ }^{1,2}$ Vidya Singh, ${ }^{3}$ N. Ebibeni, ${ }^{1}$ and Raj K. Singh ${ }^{3}$ \\ ${ }^{1}$ ICAR Research Complex for NEH Region, Jharnapani, Nagaland 797 106, India \\ ${ }^{2}$ I/C Epidemiology Section, Indian Veterinary Research Institute, Izatnagar 243122, India \\ ${ }^{3}$ NRC on Mithun, Jharnapani, Nagaland 797 106, India \\ Correspondence should be addressed to Bhoj R. Singh; brs1762@gmail.com
}

Received 25 July 2013; Revised 14 August 2013; Accepted 19 August 2013

Academic Editor: Toni L. Poole

Copyright (C) 2013 Bhoj R. Singh et al. This is an open access article distributed under the Creative Commons Attribution License, which permits unrestricted use, distribution, and reproduction in any medium, provided the original work is properly cited.

From 194 faecal dropping samples of common house geckos collected from offices (60), houses (88), integrated farm units (IFS,18) and hostels, guest houses, and dining rooms of different canteen/mess (HGM, 28), 326 bacterial isolates of enteric bacteria belonging to 17 genera and 34 species were detected. Escherichia coli were the most frequently (39) isolated followed by Citrobacter freundii (33), Klebsiella pneumonia (27), Salmonella indica (12), Enterobacter gergoviae (12), and Ent. agglomerans (11). Other important bacteria isolated from gecko droppings were Listonella damsela (2), Raoultella terrigena (3), S. salamae (2), S. houtenae (3), Edwardsiella tarda (4), Edwardsiella hoshinae (1), and Klebsiella oxytoca (2). Of the 223 isolates tested for antimicrobial drug sensitivity, 27 (12.1\%) had multiple drug resistance (MDR). None of the salmonellae or edwardsiellae had MDR however, MDR strains were significantly more common among Escherichia spp. $\left(P=1.9 \times 10^{-5}\right)$ and isolates from IFS units $\left(P=3.58 \times 10^{-23}\right)$. The most effective herbal drug, Ageratum conyzoides extract, inhibited growth of only $27.8 \%$ of strains tested followed by ethanolic extract of Zanthoxylum rhetsa (13.9\%), eucalyptus oil (5.4\%), patchouli oil (5.4\%), lemongrass oil (3.6\%), and sandalwood oil (3.1\%), and Artemisia vulgaris essential oil (3.1\%).

\section{Introduction}

In most parts of the world house wall lizards are common. In the Jharnapani area, common house gecko (Hemidactylus frenatus) is found everywhere in houses, in animal sheds, in offices, and so forth. Geckos are often reported as carriers of many zoonotic enteropathogens including nontyphoidal salmonellae [1-5], Citrobacter freundii, C. Intermedius, Erwinia herbicola, Enterobacter cloacae [2, 5], Shigella sonnei, Edwardsiella tarda, Enterobacter species, Serratia marcescens, Proteus spp., Klebsiella pneumonia, and Escherichia coli [5]. Researchers have suspected that lizards have a role as reservoirs in spread and emergence of drug resistant bacteria $[2,4,5]$. However, most of the studies on enteropathogens of public health significance in lizards have been conducted through collecting lizards, euthanizing them, and then collecting their intestinal contents, determining the presence of bacteria.

Enteric diseases often spread through contamination of environment with the faeces of patients loaded with the pathogens. Insects often try to scavenge on patients' excreta, and those insects that are eaten by house geckos may be sources of different pathogens in lizard intestine and may be detected in lizards' intestine $[2,5]$. The question we asked was what bacteria of public health concern are present in excreta of lizards which may be source of reinfection to human and animals. Though earlier studies are impressive, it is known that bacteria detected in intestines may not always be present in the excreta probably due to several competitive factors in posterior part of gastrointestinal tract. Therefore, we attempted to determine enteric bacteria in droppings of geckos instead of collecting them from intestines. Another 
query in the study was to determine the effect of the environment on bacteria present in gecko excreta. To this end, samples were collected from four different environments. Further, we determined the antimicrobial drug sensitivity of bacterial isolates from faecal dropping of geckos.

\section{Materials and Methods}

2.1. Samples. Faecal dropping of common house lizards (geckos) were collected taking care that it does not come in human or animal contact before, during or after collection of samples. To collect samples sterile masks and gloves were worn and gloves were changed after every sample. One sample constituted all the droppings collected in one enclosure/animal house, or a family home. Up to 10 droppings which had not fallen on ground, that is, still sticking on wall or roof of the room and apparently fresh, were collected in sterile $50 \mathrm{~mL}$ tube with the help of sterile forceps. In total 194 samples were collected in and around Jharnapani, Dimapur, Nagaland, India, in the months from March to June. Samples were collected from 60 offices (banks, administrative offices of district, the National Research Centre on Mithun, and the ICAR Research Complex, Jharnapani); 88 households in and around Jharnapani village of Dimapur district, residential quarters of the National Research Centre on Mithun and ICAR Research Complex, Jharnapani; 18 units of integrated farms (IFS) rearing pigs (6), rabbits (4), cows (6), ducks (1) and vegetable farming (1); 24 hostel and guest house rooms at the National Research Centre on Mithun and the ICAR Research Complex, Jharnapani; and four dining rooms (one each in a hostel, guest house, the ICAR canteen, and a the CISF mess at Jharnapani) (HGM).

2.2. Processing of Samples and Identification of Bacteria. Samples were brought to the laboratory within an hour of collection and processed for isolation of different bacteria. To each tube $20 \mathrm{~mL}$ of sterile buffered peptone (BPW, HiMedia, Mumbai) water was added. Tubes were incubated at $37^{\circ} \mathrm{C}$ for $2 \mathrm{~h}$, then swirled with a vortex mixer to mix the contents of tube uniformly, and again incubated for $6-8 \mathrm{~h}$ at $37^{\circ} \mathrm{C}$. Growth from the tubes was streaked on to MacConkey agar (MA, Hi-Media) and Hektoen enteric agar (HEA, HiMedia), and plates were incubated for $24-36 \mathrm{~h}$ at $37^{\circ} \mathrm{C}$. An example of each visibly different type of isolated colonies was picked and restreaked on brain heart infusion agar (BHIA, Hi-Media) for final isolation of bacteria. From BHIA, a single colony from each isolate was characterised using morphological, cultural, staining, and growth parameters as well as using Hi-Assorted biochemical test kit (Hi-Media) and Hi25 Enterobacteriaceae identification kit (Hi-Media) as described by the manufacturer.

2.3. Antimicrobial Sensitivity Assay. Selected isolates of different bacteria were tested for antimicrobial sensitivity using disc diffusion method [6] on the Muller Hinton agar (MHA, Hi-Media) plates against antimicrobial discs (Hi-Media) of ampicillin $(10 \mu \mathrm{g})$, cefotaxime $(30 \mu \mathrm{g})$, chloramphenicol
$(30 \mu \mathrm{g})$, ciprofloxacin $(30 \mu \mathrm{g})$, cotrimoxazole $(25 \mu \mathrm{g})$, gentamicin $(10 \mu \mathrm{g})$, nitrofurantoin $(300 \mu \mathrm{g})$, and tetracycline $(30 \mu \mathrm{g})$, and the results were interpreted as per guidelines of CLSI [6]. Isolates resistant to three or more drugs were classified as multidrug-resistant (MDR) type.

The disc diffusion method, as described earlier [7, 8], was followed for determining sensitivity of bacterial strains against herbal antimicrobials including Ageratum conyzoides ethanolic extract (AC), Artemisia vulgaris essential oil (AV), eucalyptus gum (EG), lemongrass oil (LGO), patchouli essential oil (PO), sandal wood oil (SWO), and Zanthoxylum rhetsa ethanolic extract (EO). For testing herbal drug sensitivity discs were prepared to contain $500 \mu \mathrm{g}$ of herbal preparations using sterile blank $6 \mathrm{~mm}$ discs (Hi-Media) and herbal extracts/oils kindly provided by Naga Fragrance Pvt. Ltd. Dimapur, Nagaland.

2.4. Statistical Analysis. All bacteria isolation and sensitivity assay data was entered in MS Excel work sheet and analysed to evaluate the effect of different sources of geckos on the type of bacterial strains isolated from faecal droppings and their sensitivity to antimicrobial drugs using the two-tailed Chisquare test.

\section{Results}

3.1. Bacterial Isolates from Gecko Droppings. From 194 faecal dropping samples of common house geckos collected from different places, 326 bacterial isolates were identified as belonging to 17 genera and 34 species (Table 1). Escherichia coli was isolated from the highest number of samples (39) followed by Citrobacter freundii (33), Klebsiella pneumonia (27), Salmonella indica (12), Enterobacter gregoviae (12), and Ent. agglomerans (11). Other bacteria belonging to 28 species were detected in only a few samples $(<3.2 \%)$. Detection of Ent. gergoviae $\left(P=6.3 \times 10^{-9}\right)$ and $C$. freundii $(P, 0.005)$ was significantly less common in gecko droppings in offices than from other places. On the other hand, isolation of $E$. $\operatorname{coli}\left(P=8.1 \times 10^{-7}\right)$ and $K$. pneumoniae $(P=3.4 \times$ $10^{-4}$ ) was more common from gecko droppings collected from animal houses. Salmonella salamae was detected in samples collected from human houses, while $S$. houtenae was not detected in any of the samples collected from houses, hostels, and guest houses. Detection of S. indica was also significantly $(P=0.032)$ lower in samples collected from houses than those from offices and IFS and HGM units. Some of the bacteria including C. amalonaticus, E. fergusonii, Serratia fonticola, and Pragia fontium were detected in samples collected from households, while Serratia marcescens and Xenorhabdus luminescens were present in samples collected from offices. Leclercia adecarboxylata was present only in samples collected from rabbit houses, while Ent. aerogenes and Hafnea alvei were present in samples of hostel rooms only.

Isolation of bacteria of different groups varied significantly among gecko faecal dropping samples collected from different places except edwardsiellae which were isolated 
TABLE 1: Bacterial isolates from faecal droppings of geckos collected from different sources.

\begin{tabular}{|c|c|c|c|c|c|c|c|}
\hline \multirow{2}{*}{ Bacterial isolates } & \multicolumn{5}{|c|}{$\begin{array}{l}\text { Number of gecko samples from different sources positive for bacteria } \\
\text { (number of samples tested) }\end{array}$} & \multirow{2}{*}{$\begin{array}{l}\text { Chi-test } \\
\text { statistics }\end{array}$} & \multirow{2}{*}{$\begin{array}{c}\text { Total number } \\
\text { of isolates of } \\
\text { bacteria }\end{array}$} \\
\hline & $\begin{array}{l}\text { Offices } \\
n=60\end{array}$ & $\begin{array}{c}\mathrm{HHH} \\
n=88\end{array}$ & $\begin{array}{l}\text { IFS } \\
n=18\end{array}$ & $\begin{array}{l}\text { HGM } \\
n=28\end{array}$ & $\begin{array}{l}\text { Total positive (\%) } \\
\quad N=194\end{array}$ & & \\
\hline Citrobacter diversus & 2 & 1 & 1 & 1 & $5(2.6 \%)$ & 0.657 & 9 \\
\hline C. freundii & 6 & 12 & 4 & 11 & $33(17.0 \%)$ & 0.005 & 66 \\
\hline C. amalonaticus & 0 & 6 & 0 & 0 & $6(3.1 \%)$ & 0.059 & 11 \\
\hline Edwardsiella tarda & 0 & 1 & 1 & 1 & $3(1.5 \%)$ & 0.296 & 4 \\
\hline Ed. hoshiniae & 1 & 0 & 0 & 0 & $1(0.5 \%)$ & 0.523 & 1 \\
\hline Enterobacter cloacae & 1 & 0 & 2 & 0 & $3(1.5 \%)$ & 0.005 & 3 \\
\hline Ent. aerogenese & 0 & 0 & 0 & 1 & $1(0.5 \%)$ & 0.114 & 1 \\
\hline Ent. agglomerans & 4 & 1 & 2 & 4 & $11(5.7 \%)$ & 0.039 & 13 \\
\hline Ent. amnigenus BG-I & 3 & 0 & 1 & 2 & $6(3.1 \%)$ & 0.143 & 6 \\
\hline Ent. amnigenus BG-II & 2 & 0 & 0 & 0 & $2(1.0)$ & 0.211 & 3 \\
\hline Ent. cancerogenus & 0 & 0 & 1 & 0 & $1(0.5 \%)$ & 0.020 & 1 \\
\hline Ent. gregoviae & 0 & 1 & 2 & 9 & $12(6.2 \%)$ & $6.3 \times 10^{-9}$ & 18 \\
\hline Ent. sakazaki & 0 & 1 & 0 & 0 & $1(0.5 \%)$ & 0.750 & 1 \\
\hline Erwinia ananas & 0 & 2 & 0 & 0 & $2(1.0 \%)$ & 0.487 & 2 \\
\hline Escherichia blattae & 0 & 2 & 3 & 0 & $5(2.6 \%)$ & 0.001 & 6 \\
\hline E. coli & 4 & 17 & 12 & 6 & $39(20.1 \%)$ & $8.1 \times 10^{-7}$ & 56 \\
\hline E. fergusonii & 0 & 3 & 0 & 0 & $3(1.5 \%)$ & 0.299 & 3 \\
\hline Hafnea alvei & 0 & 0 & 0 & 1 & $1(0.5 \%)$ & 0.114 & 1 \\
\hline Klebsiella oxytoca & 0 & 1 & 0 & 1 & $2(1.0 \%)$ & 0.459 & 2 \\
\hline K. pneumoniae & 5 & 7 & 7 & 8 & $27(13.9 \%)$ & $3.4 \times 10^{-4}$ & 41 \\
\hline $\begin{array}{l}\text { Leclercia } \\
\text { adecarboxylata }\end{array}$ & 0 & 0 & 1 & 0 & $1(0.5 \%)$ & 0.020 & 1 \\
\hline Leminorella ghirmonti & 1 & 1 & 0 & 0 & $2(1.0 \%)$ & 0.867 & 2 \\
\hline Listonella damsele & 1 & 0 & 1 & 0 & $2(1.0 \%)$ & 0.168 & 3 \\
\hline Pragia fontium & 0 & 6 & 0 & 0 & $6(3.1 \%)$ & 0.059 & 6 \\
\hline Proteus penneri & 1 & 1 & 0 & 0 & $2(1.0 \%)$ & 0.867 & 2 \\
\hline $\begin{array}{l}\text { Pseudomonas } \\
\text { aeruginosa }\end{array}$ & 0 & 1 & 2 & 0 & $3(1.5 \%)$ & 0.006 & 3 \\
\hline Raoultella terrigena & 1 & 2 & 0 & 0 & $3(1.5 \%)$ & 0.793 & 4 \\
\hline Salmonella indica & 6 & 1 & 3 & 2 & $12(6.2 \%)$ & 0.032 & 36 \\
\hline Salmonella salamae & 0 & 2 & 0 & 0 & $2(1.0 \%)$ & 0.487 & 7 \\
\hline Salmonella houtenae & 2 & 0 & 1 & 0 & $3(1.5 \%)$ & 0.173 & 4 \\
\hline Serratia entamophila & 2 & 0 & 0 & 0 & $2(1.0 \%)$ & 0.523 & 3 \\
\hline Serratia fonticola & 0 & 1 & 0 & 0 & $1(0.5 \%)$ & 0.750 & 4 \\
\hline Serratia marcescens & 1 & 0 & 0 & 0 & $1(0.5 \%)$ & 0.523 & 2 \\
\hline $\begin{array}{l}\text { Xenorhabdus } \\
\text { luminescens }\end{array}$ & 1 & 0 & 0 & 0 & $1(0.5 \%)$ & 0.523 & 1 \\
\hline Total & 44 & 70 & 18 & 28 & 160 & 0.003 & 326 \\
\hline
\end{tabular}

HHH: human households; IFS: integrated farm units; HGM: hostel, guest house, and mess/canteen; BG: biogroup; NT: not tested.

Note: Chi-square test was done to test the null hypothesis that sources from which gecko droppings were sampled had no effect on isolation rate of the bacteria.

from samples at all different sources. At least one Enterobacteriaceae member was detected in 44 samples from offices and in 70 of the 88 samples collected from different houses. Additionally, one or more members of Enterobacteriaceae were isolated from all samples of gecko droppings collected from IFS and HGM units.
3.2. Antimicrobial Drug Resistance in Bacteria Isolated from Gecko Droppings. Out of 326 bacterial isolates from gecko faecal droppings, 223 were tested for antimicrobial drug resistance against eight drugs including ampicillin, cefotaxime, ciprofloxacin, chloramphenicol, cotrimoxazole, gentamicin, nitrofurantoin, and tetracycline. Those strains resistant to 
TABLE 2: Antimicrobial drug resistance of bacteria isolated from faecal droppings of geckos.

\begin{tabular}{|c|c|c|c|c|c|c|c|c|c|c|}
\hline \multirow{2}{*}{ Bacteria } & \multirow{2}{*}{ Total isolates tested } & \multicolumn{8}{|c|}{ Number of isolates resistant to antimicrobial discs of } & \multirow{2}{*}{ MDR strains } \\
\hline & & A & CTX & $\mathrm{C}$ & $\mathrm{Cf}$ & Co & G & $\mathrm{Nf}$ & $\mathrm{T}$ & \\
\hline Citrobacter diversus & 3 & 1 & 0 & 0 & 0 & 0 & 0 & 3 & 0 & 0 \\
\hline C. freundii & 43 & 23 & 2 & 2 & 1 & 4 & 1 & 15 & 0 & 3 \\
\hline C. amalonaticus & 3 & 0 & 0 & 0 & 0 & 1 & 0 & 1 & 0 & 0 \\
\hline Edwardsiella tarda & 4 & 0 & & 0 & 0 & 0 & 0 & 1 & 0 & 0 \\
\hline Ed. hoshiniae & 1 & 0 & 0 & 0 & 0 & 0 & 0 & 0 & 0 & 0 \\
\hline Enterobacter cloacae & 3 & 1 & 1 & 0 & 0 & 0 & 0 & 0 & 0 & 0 \\
\hline Ent. agglomerans & 2 & 1 & 0 & 0 & 0 & 0 & 0 & 0 & 0 & 0 \\
\hline Ent. amnigenus BG-I & 5 & 3 & 0 & 0 & 0 & 0 & 0 & 0 & 0 & 0 \\
\hline Ent. amnigenus BG-II & 3 & 2 & 1 & 0 & 0 & 2 & 0 & 0 & 0 & 1 \\
\hline Ent. cancerogenus & 1 & 1 & 1 & 1 & 0 & 0 & 0 & 1 & 0 & 1 \\
\hline Ent. gregoviae & 5 & 4 & 0 & 1 & 0 & 0 & 0 & 3 & 0 & 1 \\
\hline Ent. sakazaki & 1 & 0 & 0 & 0 & 0 & 0 & 0 & 0 & 0 & 0 \\
\hline Erwinia ananas & 1 & 0 & 0 & 0 & 0 & 0 & 0 & 0 & 0 & 0 \\
\hline Escherichia blattae & 6 & 3 & 1 & 3 & 0 & 5 & 1 & 2 & 0 & 3 \\
\hline E. coli & 44 & 13 & 7 & 6 & 2 & 14 & 0 & 10 & 8 & 8 \\
\hline E. fergusonii & 1 & 0 & 0 & 0 & 0 & 0 & 0 & 0 & 0 & 0 \\
\hline Hafnea alvei & 1 & 0 & 0 & 0 & 0 & 0 & 0 & 0 & 0 & 0 \\
\hline Klebsiella oxytoca & 2 & 2 & 0 & 0 & 0 & 0 & 0 & 1 & 0 & 0 \\
\hline K. pneumoniae & 35 & 35 & 2 & 3 & 0 & 4 & 0 & 23 & 1 & 5 \\
\hline Leminorella ghrimontii & 1 & 0 & 0 & 0 & 0 & 0 & 0 & 0 & 0 & 0 \\
\hline Listonella damsele & 3 & 2 & 3 & 0 & 0 & 2 & 0 & 0 & 0 & 2 \\
\hline Pragia fontium & 4 & 3 & 0 & 0 & 0 & 0 & 0 & 1 & 0 & 0 \\
\hline Proteus penneri & 2 & 0 & 0 & 1 & 0 & 1 & 0 & 1 & 1 & 1 \\
\hline Pseudomonas aeruginosa & 3 & 2 & 0 & 3 & 0 & 0 & 0 & 3 & 0 & 2 \\
\hline Raoultella terrigena & 3 & 3 & 0 & & 0 & 0 & 0 & 0 & 0 & 0 \\
\hline Salmonella indica & 30 & 4 & 0 & 0 & 0 & 1 & 0 & 2 & 0 & 0 \\
\hline Salmonella salamae & 7 & 7 & 0 & 0 & 0 & 0 & 0 & 0 & 0 & 0 \\
\hline Salmonella houtenae & 4 & 1 & 0 & 0 & 0 & 0 & 0 & 0 & 1 & 0 \\
\hline Serratia fonticola & 1 & 0 & & 0 & 0 & 0 & 0 & 0 & 0 & 0 \\
\hline Serratia marcescens & 1 & 1 & 0 & 0 & 0 & 0 & 0 & 1 & 0 & 0 \\
\hline Total & 223 & 112 & 18 & 20 & 3 & 34 & 2 & 68 & 11 & 27 \\
\hline$\%$ resistant strains & & 50.2 & 8.1 & 9.0 & 1.3 & 15.2 & 0.9 & 30.5 & 4.9 & \\
\hline Chi-test values & & $7.6 \times 10^{-9}$ & $2.6 \times 10^{-4}$ & $5.6 \times 10^{-5}$ & 0.999 & $5.6 \times 10^{-4}$ & 0.911 & $6.5 \times 10^{-5}$ & 0.172 & $9.2 \times 10^{-3}$ \\
\hline
\end{tabular}

A: ampicillin $10 \mu \mathrm{g}$; CTX: cefotaxime $30 \mu \mathrm{g}$; C: chloramphenicol $30 \mu \mathrm{g}$; Cf: ciprofloxacin $5 \mu \mathrm{g}$; Co: cotrimoxazole $25 \mu \mathrm{g}$; G: gentamicin $10 \mu \mathrm{g}$; Nf: nitrofurantoin $300 \mu \mathrm{g}$; T: tetracycline $30 \mu \mathrm{g}$.

Note: Chi-square test was done to test the null hypothesis that type of bacteria had no effect on resistance to antimicrobial drug.

three or more drugs were classified as multidrug-resistant (MDR) strains. Only 27 (12.1\%) isolates were MDR type. Among all major groups of bacteria isolated from gecko droppings, MDR strains were detected (Table 2). However, none of 41 salmonellae (S. indica 30, S. salamae 7, S. houtenae 4) nor 5 edwardsiellae (Ed. tarda 4, Ed. hoshiniae 1) strains demonstrated MDR. Of the total 223 strains tested, 73 were not resistant to any of the 8 drugs, while 72, 51, 20, and 4 strains were resistant to one, two, three, and four drugs, respectively. Only one isolate each was resistant to 5 ( $E$. coli, from rabbitry), 6 (E. coli, from piggery) and 7 (E. coli, from rabbitry) drugs. MDR strains were significantly more common among Escherichia spp. $\left(P=1.9 \times 10^{-5}\right)$ and in isolates from IFS units (17 of $27 \mathrm{MDR}$ ). Among 51 tested isolates of bacteria collected from IFS, 17 were MDR type; the proportion was significantly $\left(P=3.58 \times 10^{-23}\right)$ higher than that of isolates from samples collected from offices ( 3 of 51), households (6 of 68), and HGM (1 of 53).

Antimicrobial drug resistance assay results revealed (Table 2) that most of the bacterial isolates from gecko droppings were sensitive to gentamicin (99.1\%), ciprofloxacin (98.7\%), tetracycline (95.1\%), cefotaxime (91.9\%), chloramphenicol (91\%, cotrimoxazole), and nitrofurantoin (69.5\%). However, more than $50 \%$ of isolates were resistant to ampicillin. Resistance of different bacterial strains varied significantly $\left(P=2.6 \times 10^{-4}\right.$ to $\left.7.6 \times 10^{-9}\right)$ for all the antimicrobials except for gentamicin, ciprofloxacin, and tetracycline (Table 2). 
TABLE 3: Antimicrobial herbal-drug resistance of bacteria isolated from faecal droppings of geckos.

\begin{tabular}{|c|c|c|c|c|c|c|c|c|}
\hline \multirow{2}{*}{ Bacteria } & \multirow{2}{*}{ Isolates tested } & \multicolumn{7}{|c|}{ Number of isolates resistant to } \\
\hline & & $\mathrm{AC}$ & $\mathrm{AV}$ & EG & LGO & $\mathrm{PO}$ & SWO & ZR \\
\hline Citrobacter diversus & 3 & 1 & 3 & 2 & 3 & 2 & 3 & 1 \\
\hline C. amalonaticus & 3 & 2 & 2 & 3 & 3 & 3 & 3 & 3 \\
\hline C. freundii & 43 & 27 & 42 & 42 & 43 & 43 & 42 & 33 \\
\hline Edwardsiella tarda & 4 & 3 & 4 & 4 & 3 & 4 & 4 & 4 \\
\hline Ed. hoshiniae & 1 & 1 & 1 & 1 & 1 & 1 & 1 & 1 \\
\hline Enterobacter cloacae & 3 & 1 & 3 & 2 & 3 & 3 & 3 & 3 \\
\hline Ent. agglomerans & 2 & 2 & 2 & 2 & 2 & 2 & 2 & 2 \\
\hline Ent. amnigenus BG-I & 5 & 5 & 5 & 5 & 5 & 5 & 5 & 5 \\
\hline Ent. amnigenus BG-II & 3 & 2 & 2 & 0 & 1 & 1 & 2 & 1 \\
\hline Ent. cancerogenus & 1 & 1 & 1 & 1 & 1 & 1 & 1 & 1 \\
\hline Ent. gregoviae & 5 & 4 & 5 & 5 & 5 & 4 & 5 & 3 \\
\hline Ent. sakazaki & 1 & 1 & 1 & 1 & 1 & 1 & 1 & 0 \\
\hline Erwinia ananas & 1 & 1 & 1 & 1 & 1 & 1 & 1 & 0 \\
\hline Escherichia coli & 44 & 39 & 44 & 44 & 43 & 42 & 43 & 41 \\
\hline E. blattae & 6 & 4 & 6 & 6 & 6 & 6 & 6 & 6 \\
\hline E. fergusonii & 1 & 1 & 1 & 1 & 1 & 1 & 1 & 1 \\
\hline Hafnea alvei & 1 & 0 & 1 & 1 & 1 & 1 & 1 & 0 \\
\hline Klebsiella oxytoca & 2 & 0 & 2 & 2 & 2 & 2 & 2 & 2 \\
\hline K. pneumoniae & 35 & 27 & 34 & 35 & 35 & 35 & 35 & 32 \\
\hline Leminorella ghrimontii & 1 & 0 & 1 & 0 & 1 & 1 & 1 & 1 \\
\hline Listonella damsele & 3 & 1 & 0 & 0 & 0 & 0 & 0 & 3 \\
\hline Pragia fontium & 4 & 4 & 4 & 4 & 4 & 4 & 4 & 4 \\
\hline Proteus penneri & 2 & 2 & 2 & 1 & 2 & 2 & 2 & 2 \\
\hline Pseudomonas aeruginosa & 3 & 3 & 3 & 3 & 3 & 3 & 3 & 3 \\
\hline Raoultella terrigena & 3 & 1 & 3 & 3 & 3 & 3 & 3 & 1 \\
\hline Salmonella indica & 30 & 18 & 30 & 29 & 29 & 27 & 29 & 28 \\
\hline Salmonella salamae & 7 & 7 & 7 & 7 & 7 & 7 & 7 & 7 \\
\hline Salmonella houtenae & 4 & 2 & 4 & 4 & 4 & 4 & 4 & 4 \\
\hline Serratia fonticola & 1 & 0 & 1 & 1 & 1 & 1 & 1 & 0 \\
\hline Serratia marcescens & 1 & 1 & 1 & 1 & 1 & 1 & 1 & 0 \\
\hline Total & 223 & 161 & 216 & 211 & 215 & 211 & 216 & 192 \\
\hline$\%$ resistant strains & & 72.2 & 96.9 & 94.6 & 96.4 & 94.6 & 96.9 & 86.1 \\
\hline Chi-test values & & 0.029 & $3.3 \times 10^{-12}$ & $4.7 \times 10^{-18}$ & $4.9 \times 10^{-14}$ & $2.9 \times 10^{-8}$ & $1.5 \times 10^{-10}$ & $2.8 \times 10^{-5}$ \\
\hline
\end{tabular}

All herbal antimicrobials were used as $0.5 \mathrm{mg} /$ disc; AC: Ageratum conyzoides ethanolic extract; AV: Artemisia vulgaris essential oil; EG: eucalyptus gum; LGO: lemongrass oil; PO: patchouli essential oil; SWO: sandalwood oil; ZR: Zanthoxylum rhetsa ethanolic extract.

Note: Chi-square test was done to test the null hypothesis that type of bacteria had no effect on resistance to antimicrobial drug.

3.3. Antimicrobial Herbal Drug Resistance in Bacteria Isolated from Gecko Droppings. In contrast to antimicrobial drugs, herbal antimicrobials were effective to inhibit growth of only a few bacteria isolated from gecko droppings. Even the most effective herbal drug (Table 3), Ageratum conyzoides extract, was less effective than any of the commercially available antimicrobials used in the study (ampicillin). Among antimicrobial herbal drugs, ethanolic extract of $A$. conyzoides was effective on the largest number $(27.8 \%)$ of strains followed by ethanolic extract of Zanthoxylum rhetsa (13.9\%), eucalyptus oil (5.4\%), patchouli oil (5.4\%), lemongrass oil (3.6\%), sandalwood oil (3.1\%), and Artemisia vulgaris essential oil (3.1\%). Resistance to herbal drugs significantly $(P=0.029$ to $4.7 \times 10^{-18}$ ) varied among strains of different bacteria (Table 3).

Resistance of bacterial isolates to ampicillin $(P=0.61)$, ciprofloxacin $(P=0.26), A$. vulgaris $(P=0.62)$, lemongrass oil $(P=0.10)$, sandalwood oil $(P=0.10)$, and gentamicin $(P=0.08)$ was little affected by the source of sample. However, for other antimicrobials, the source of the sample affected significantly $\left(P=0.024\right.$ to $\left.5.6 \times 10^{-5}\right)$ the outcome (Table 4$)$. Though there was no significant effect of source of sample on resistance of bacterial isolates to ampicillin, effect of ampicillin greatly varied $P=1.7 \times 10^{-10}$ ) with the type of bacteria. All strains of Klebsiella and Raoultella were resistant, and all strains of Edwardsiella were sensitive 
TABLE 4: Effect of source of geckos on antimicrobial drug resistance (\% strains) in bacterial isolates from faecal droppings of geckos.

\begin{tabular}{|c|c|c|c|c|c|c|}
\hline \multirow{2}{*}{$\begin{array}{l}\text { Antimicrobial drug } \\
\text { (content in disc) }\end{array}$} & \multicolumn{4}{|c|}{$\begin{array}{l}\text { \% Resistant isolates of bacteria isolated from lizards } \\
\text { of different sources (number of isolates tested) }\end{array}$} & \multirow[b]{2}{*}{ Total (223) } & \multirow{2}{*}{$\begin{array}{l}\text { Chi-test } \\
\text { statistics }\end{array}$} \\
\hline & Office (51) & HHH (68) & IFS (51) & HGM (53) & & \\
\hline Ampicillin $(10 \mu \mathrm{g})$ & 47.1 & 45.6 & 52.9 & 56.6 & 50.2 & 0.614 \\
\hline Cefotaxime $(30 \mu \mathrm{g})$ & 7.8 & 2.9 & 21.6 & 1.9 & 8.1 & $5.2 \times 10^{-4}$ \\
\hline Chloramphenicol $(30 \mu \mathrm{g})$ & 0 & 10.3 & 23.5 & 1.9 & 9 & $7.6 \times 10^{-5}$ \\
\hline Ciprofloxacin $(5 \mu \mathrm{g})$ & 0 & 1.5 & 3.9 & 0 & 1.3 & 0.264 \\
\hline Cotrimoxazole $(25 \mu \mathrm{g})$ & 9.8 & 23.5 & 21.6 & 3.8 & 15.2 & $8.3 \times 10^{-3}$ \\
\hline Gentamicin $(10 \mu \mathrm{g})$ & 0 & 0 & 3.9 & 0 & 0.9 & 0.783 \\
\hline Nitrofurantoin $(300 \mu \mathrm{g})$ & 3.9 & 36.8 & 41.2 & 37.7 & 30.5 & $5.6 \times 10^{-5}$ \\
\hline Tetracycline $(30 \mu \mathrm{g})$ & 0 & 2.9 & 15.7 & 1.9 & 4.9 & $7.6 \times 10^{-4}$ \\
\hline $\mathrm{AC}(500 \mu \mathrm{g})$ & 66.7 & 85.3 & 82.4 & 50.9 & 72.2 & $1.0 \times 10^{-4}$ \\
\hline $\mathrm{AV}(500 \mu \mathrm{g})$ & 94.1 & 97.1 & 98 & 98.1 & 96.9 & 0.620 \\
\hline EG $(500 \mu \mathrm{g})$ & 86.3 & 95.6 & 96.1 & 100 & 94.6 & 0.016 \\
\hline LGO $(500 \mu \mathrm{g})$ & 92.2 & 100 & 98 & 94.3 & 96.4 & 0.100 \\
\hline PO $(500 \mu \mathrm{g})$ & 84.3 & 100 & 92.2 & 100 & 94.6 & $4.1 \times 10^{-4}$ \\
\hline SWO $(500 \mu \mathrm{g})$ & 92.2 & 98.5 & 96.1 & 100 & 96.9 & 0.104 \\
\hline $\mathrm{ZR}(500 \mu \mathrm{g})$ & 90.2 & 88.2 & 92.2 & 73.6 & 86.1 & 0.024 \\
\hline
\end{tabular}

AC: Ageratum conyzoides ethanolic extract; AV: Artemisia vulgaris essential oil; EG: eucalyptus gum; LGO: lemongrass oil; PO: patchouli essential oil; SWO: sandalwood oil; ZR: Zanthoxylum rhetsa ethanolic extract; HHH: human house-holds; IFS: integrated farm units; HGM: hostel, guest house and mess/canteen. Note: Chi-square test was done to test the null hypothesis that source of bacteria had no effect on resistance to antimicrobial drug.

to ampicillin (Table 5). A similar difference was also evident among strains of different bacteria for effect of nitrofurantoin ( $>65 \%$ of klebsiellae, $>38 \%$ of citrobacteria, and about $25 \%$ of Escherichia strains were resistant) and cotrimoxazole (>37\% of $E$. coli strains were resistant, while $<12 \%$ strains of other bacteria had resistance). However, efficacy of ciprofloxacin $(P=0.62)$, gentamicin $(P=0.87)$, and $A$. conyzoides $(P=$ 0.12 ) was barely affected by the species or genus of bacteria (Table 5).

\section{Discussion}

It is widely accepted that potentially enteropathogenic and zoonotically important bacteria may be present in intestine of geckos (common house lizards), and thus the geckos have been seen as potential threat in spread of enteric diseases [15]. This study was conducted to determine if enteric bacteria are actually present in faecal droppings of geckos, because not all intestinal bacteria are excreted in faeces of geckos.

In the study, bacteria belonging to 34 species of 17 genera were detected in faecal dropping of geckos. Many of the bacteria isolated from faecal droppings of geckos have been reported earlier in intestinal contents including nontyphoidal salmonellae [1-5]; Citrobacter freundii, Enterobacter cloacae [2, 5], Edwardsiella tarda, Enterobacter species, Serratia marcescens, Proteus spp., Klebsiella pneumonia, and Escherichia coli [5]. However, many of bacteria reported earlier including several Salmonella serovars of $S$. enterica ssp. enterica $[1,3], C$. intermedius, Erwinia herbicola [2, 5], and Shigella sonnei [5] could not be isolated possibly due to differences in time and geography of sampling. Instead, several Salmonella (S. indica, S. slamae, and
S. houtenae), Klebsiella oxytoca, Raoultella terrigena, Edwardsiella hoshiniae, Listonella damsele, Leclercia adecarboxylata, and Lemionorella ghrimontii are reported here for the first time from gecko faecal droppings. The isolation of bacteria of 34 species from gecko droppings provides a glimpse in to diversity of faecal microbiota of geckos. The bacterial population in gecko droppings may vary significantly under different environments as droppings collected from geckos living at different places had significant difference in bacterial population of droppings.

Drug resistance has been reported to be of great concern in bacteria isolated from geckos $[2,4,5]$, and in the present study $12.1 \%$ strains had resistance to three or more drugs. Low rates of drug resistance in bacteria from droppings of geckos observed in the present study might be due to lesser loads of antibiotics in environment. This view is further supported by the fact that $>33 \%$ bacteria isolated from droppings of geckos residing in IFS units were MDR type. In IFS, the use of antibiotics is common [9]; therefore, isolation of MDR strains from droppings of geckos living in IFS units appears to be non surprising. Thus it can be concluded that it is not the gecko but the environment which prompts the presence of MDR strains. Further, well-designed studies need to be conducted to determine whether or not geckos concentrate and propagate MDR strains or not. Besides environment, inherent drug resistance of certain bacteria might have also contributed to persistence of drug resistant microbes in gecko faeces. All klebsiellae were resistant to ampicillin which is an inherent quality of most the Klebsiella and Raoultella strains [10].

Resistance to herbal antimicrobials was remarkably high among bacterial strains of gecko origin, and none of 
TABle 5: Variation in antimicrobial drug resistance (\% strains) among different groups of bacteria isolated from faecal droppings of geckos.

\begin{tabular}{|c|c|c|c|c|c|c|c|c|c|}
\hline \multirow[b]{2}{*}{$\begin{array}{l}\text { Antimicrobial drugs } \\
\text { used (contents in } \\
\text { disc) }\end{array}$} & \multicolumn{8}{|c|}{$\%$ resistant isolates of different groups of bacteria (number of isolates tested) } & \multirow[b]{2}{*}{ Chi-test statistics } \\
\hline & $\begin{array}{l}\text { Citro- } \\
\text { bacter spp. } \\
\quad(49)\end{array}$ & $\begin{array}{l}\text { Edward- } \\
\text { siella spp. } \\
\quad(5)\end{array}$ & $\begin{array}{l}\text { Entero- } \\
\text { bacter spp. } \\
\quad(20)\end{array}$ & $\begin{array}{l}\text { Escheri- } \\
\text { chia } \\
\text { spp. (51) }\end{array}$ & $\begin{array}{l}\text { Klebsiella } \\
\text { spp. (37) }\end{array}$ & $\begin{array}{l}\text { Salmo- } \\
\text { nella } \\
\text { enterica } \\
(41)\end{array}$ & $\begin{array}{c}\text { Other } \\
\text { bacteria } \\
(20)\end{array}$ & Total (223) & \\
\hline $\mathrm{A}(10 \mu \mathrm{g})$ & 49 & 0 & 60 & 31.4 & 100 & 29.3 & 55 & 50.2 & $1.7 \times 10^{-10}$ \\
\hline CTX $(30 \mu \mathrm{g})$ & 4.1 & 0 & 15 & 15.7 & 5.4 & 0 & 15 & 8.1 & 0.062 \\
\hline $\mathrm{C}(30 \mu \mathrm{g})$ & 4.1 & 0 & 10 & 17.6 & 8.1 & 0 & 20 & 9 & 0.033 \\
\hline $\mathrm{Cf}(5 \mu \mathrm{g})$ & 2 & 0 & 0 & 3.9 & 0 & 0 & 0 & 1.3 & 0.622 \\
\hline Co $(25 \mu \mathrm{g})$ & 10.2 & 0 & 10 & 37.3 & 10.8 & 2.4 & 15 & 15.2 & $1.3 \times 10^{-4}$ \\
\hline $\mathrm{G}(10 \mu \mathrm{g})$ & 2 & 0 & 0 & 2 & 0 & 0 & 0 & 0.9 & 0.870 \\
\hline $\mathrm{Nf}(300 \mu \mathrm{g})$ & 38.8 & 20 & 20 & 23.5 & 64.9 & 4.9 & 30 & 30.5 & $1.5 \times 10^{-6}$ \\
\hline $\mathrm{T}(30 \mu \mathrm{g})$ & 0 & 0 & 0 & 15.7 & 2.7 & 2.4 & 5 & 4.9 & 0.008 \\
\hline $\mathrm{AC}(500 \mu \mathrm{g})$ & 61.2 & 80 & 80 & 86.3 & 73 & 65.9 & 65 & 72.2 & 0.121 \\
\hline $\mathrm{AV}(500 \mu \mathrm{g})$ & 95.9 & 100 & 95 & 100 & 97.3 & 100 & 85 & 96.9 & 0.046 \\
\hline EG $(500 \mu \mathrm{g})$ & 95.9 & 100 & 80 & 100 & 100 & 97.6 & 75 & 94.6 & $4.6 \times 10^{-5}$ \\
\hline LGO $(500 \mu \mathrm{g})$ & 100 & 80 & 90 & 98 & 100 & 97.6 & 85 & 96.4 & 0.007 \\
\hline $\mathrm{PO}(500 \mu \mathrm{g})$ & 98 & 100 & 85 & 96.1 & 100 & 92.7 & 85 & 94.6 & 0.081 \\
\hline SWO $(500 \mu \mathrm{g})$ & 98 & 100 & 95 & 98 & 100 & 97.6 & 85 & 96.9 & 0.079 \\
\hline $\mathrm{ZR}(500 \mu \mathrm{g})$ & 75.5 & 100 & 75 & 94.1 & 91.9 & 95.1 & 70 & 86.1 & 0.005 \\
\hline
\end{tabular}

Other bacteria include isolates of Erwinia ananas, hafnea alvei, Leclercia adecarboxylata, Leminorella ghirmonti, Listonella damsel, Pragia fontium, Proteus penneri, Pseudomonas aeruginosa, Raoultella terrigena, Serratia fonticola, Serratia marcescens, and Xenorhabdus luminescens.

A: ampicillin; CTX: cefotaxime; C: chloramphenicol; Cf: ciprofloxacin; Co: cotrimoxazole; G: gentamicin; Nf: nitrofurantoin; T: tetracycline; AC: Ageratum conyzoides ethanolic extract; AV: Artemisia vulgaris essential oil; EG: eucalyptus gum; LGO: lemongrass oil; PO: patchouli essential oil; SWO: sandalwood oil; ZR: Zanthoxylum rhetsa ethanolic extract.

Note: Chi-square test was done to test the null hypothesis that type of bacteria had no effect on resistance to antimicrobial drug.

the herbal preparations were able to inhibit growth of $>27.8 \%$ isolates. Herbal drugs are often reported to be important alternatives for MDR strains, and it is shown that bacteria can not develop resistance to herbal medicines [11-13]; however, our observations contradict with these findings. The reason for the contrasting observations might be due to the selection of strains for testing against herbal drugs in earlier studies or might be due to the changing environment. Further, earlier opinions [11-13] might be based on the studies conducted on a few selected bacterial strains, while in our study all isolates of bacteria from gecko droppings were tested, which might have made us to record resistance for herbal preparations in microbes. Moreover, Nagaland is a rich source of herbs in India, and this presence/abundance of herbs in environment may result in the selection of herbal drug resistant strains similar to antimicrobial drugs [11-13]. In the present study, there was a significant difference in sensitivity of different bacteria to herbal drugs indicating that herbal drugs also kill bacteria selectively and are not broad spectra. Similar observations have also been made earlier and enteric bacteria are often reported more resistant than other bacteria to herbal drugs $[7,8,14-16]$.

This study concluded that enteric bacteria in gecko faecal droppings and their drug resistance pattern vary significantly depending on geckos' surroundings. Bacteria isolated were usually sensitive to most of the commercially available antimicrobials but resistant to most of the herbal drugs claimed to have good antimicrobial activity.

\section{Acknowledgments}

The authors are thankful to the Director and the Joint Director of ICAR Research Complex for NEH Region, Jharnapani, for permitting to work, providing laboratory facility and the financial support. The authors also acknowledge day-to-day support in laboratory and also in collecting samplings from different places by Moa. They also thank the different IFS units incharge of Jharnapani for permitting to frequently visit their farms and collect the samples.

\section{References}

[1] Y. K. Kaura and I. P. Singh, "Prevalence of Salmonellae in some of the common wall lizards, birds and rodents," The Indian Journal of Medical Research, vol. 56, no. 8, pp. 1174-1179, 1968.

[2] A. Kumar and V. K. Sharma, "Enterobacteria of emerging pathogenic significance from clinical cases in man and animals and detection of toads and wall lizards as their reservoirs," Antonie van Leeuwenhoek, vol. 44, no. 2, pp. 219-228, 1978.

[3] B. R. Gupta, S. C. Pal, and A. S. Narula, "Isolation of salmonellae from wall lizards and non-agglutinating vibrios from frogs," Journal of Communicable Diseases, vol. 12, no. 3, pp. 148-150, 1980.

[4] S. I. Oboegbulem and A. U. Iseghohimhen, "Wall geckos (Geckonidae) as reservoirs of Salmonellae in Nigeria: problems for epidemiology and public health," International Journal of Zoonoses, vol. 12, no. 3, pp. 228-232, 1985. 
[5] H. C. Gugnani, J. U. Oguike, and R. Sakazaki, "Salmonellae and other enteropathogenic bacteria in the intestines of wall geckos in Nigeria," Antonie van Leeuwenhoek, vol. 52, no. 2, pp. 117-120, 1986.

[6] Clinical and laboratory standards institute (CLSI), "Performance standards for antimicrobial disk susceptibility tests," Documents M02-A9, and M100-S18, 17th Informational Supplement, Wayne, Pennsylvania, 9th edition, 2006.

[7] B. R. Singh, V. Singh, R. K. Singh, and N. Ebibeni, "Antimicrobial activity of lemongrass (Cymbopogon citratus) oil against microbes of environmental, clinical and food origin," International Research Journal of Pharmacy and Pharmacology, vol. 1, pp. 228-236, 2011.

[8] B. R. Singh, V. Singh, R. K. Singh, S. Toppo, N. Haque, and N. Ebibeni, "Antimicrobial effect of Artemisia Vulgaris essential oil," Natural Products, vol. 7, pp. 5-12, 2011.

[9] B. R. Singh, "Environmental health risks from integrated farming system (IFS)," in Environmental Health: Human and Animal Risk Mitigation, S. R. Garg, Ed., pp. 373-383, CBS publishers, Lucknow, India, 2011.

[10] B. R. Singh and V. D. Sharma, "Klebsiella, an emerging pathogen of zoonotic significance, its pathogenic potential, adhesions, transmission and control," Indian Journal of Comparative Microbiology Immunology and Infectious Diseases, vol. 20, pp. 79-90, 1999.

[11] A. Nostro, "Activity of plant extracts and plant-derived compounds against drug-resistant microorganisms," in Modern Phytomedicine, I. Ahmad, F. Aqil, and M. Owais, Eds., pp. 199231, Wiley-VCH, Weinheim, Germany, 2006.

[12] P. H. Warnke, S. T. Becker, R. Podschun et al., "The battle against multi-resistant strains: renaissance of antimicrobial essential oils as a promising force to fight hospital-acquired infections," Journal of Cranio-Maxillofacial Surgery, vol. 37, no. 7, pp. 392397, 2009.

[13] V. A. Reiner, "Essential oils versus MRSA: viruses, bacteria can not develop resistance to natural ingredients," 2008, http://suite101.com/article/essential-oils-versus-mrsa-a50478 \#ixzz275BnVJ1q.

[14] B. R. Singh, V. Singh, R. K. Singh, S. Toppo, N. Haque, and N. Ebibeni, "Comparative evaluation of antimicrobial effect of Artemisia vulgaris essential oils extracted from fresh and dried herb," Medicinal Plants, vol. 4, pp. 76-82, 2012.

[15] B. R. Singh, V. Singh, R. K. Singh, S. Toppo, N. Haque, and N. Ebibeni, "Antimicrobial activity on common pathogens in essential oil of aerial parts of Selinum wallichianum," Natural Products, vol. 8, pp. 233-237, 2012.

[16] B. R. Singh, "Antimicrobial drug resistance against Eucalyptus citriodora gum in strains of common microbes of public health concern isolated from food, animals and environment," Natural Products, vol. 9, pp. 153-160, 2013. 

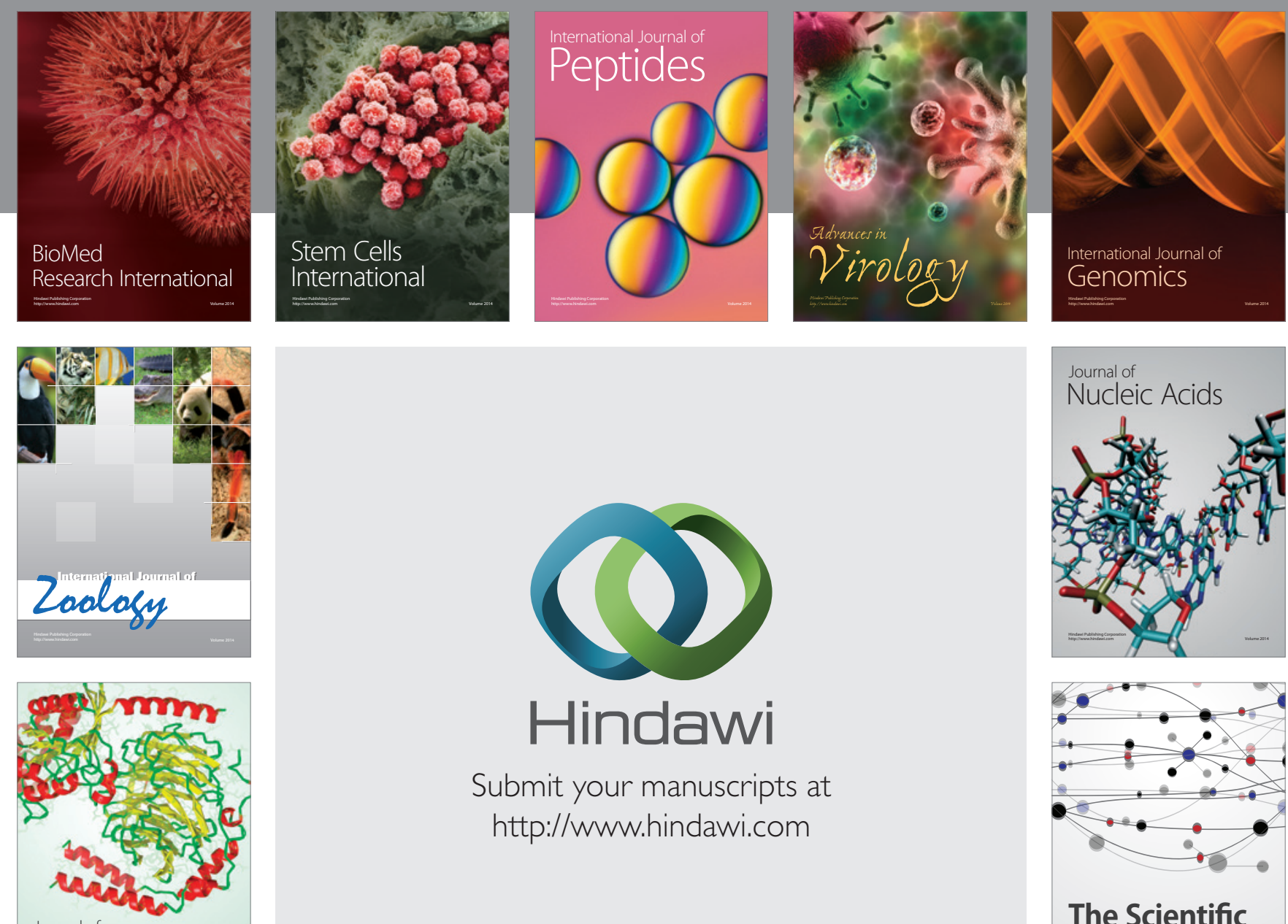

Submit your manuscripts at

http://www.hindawi.com

Journal of
Signal Transduction
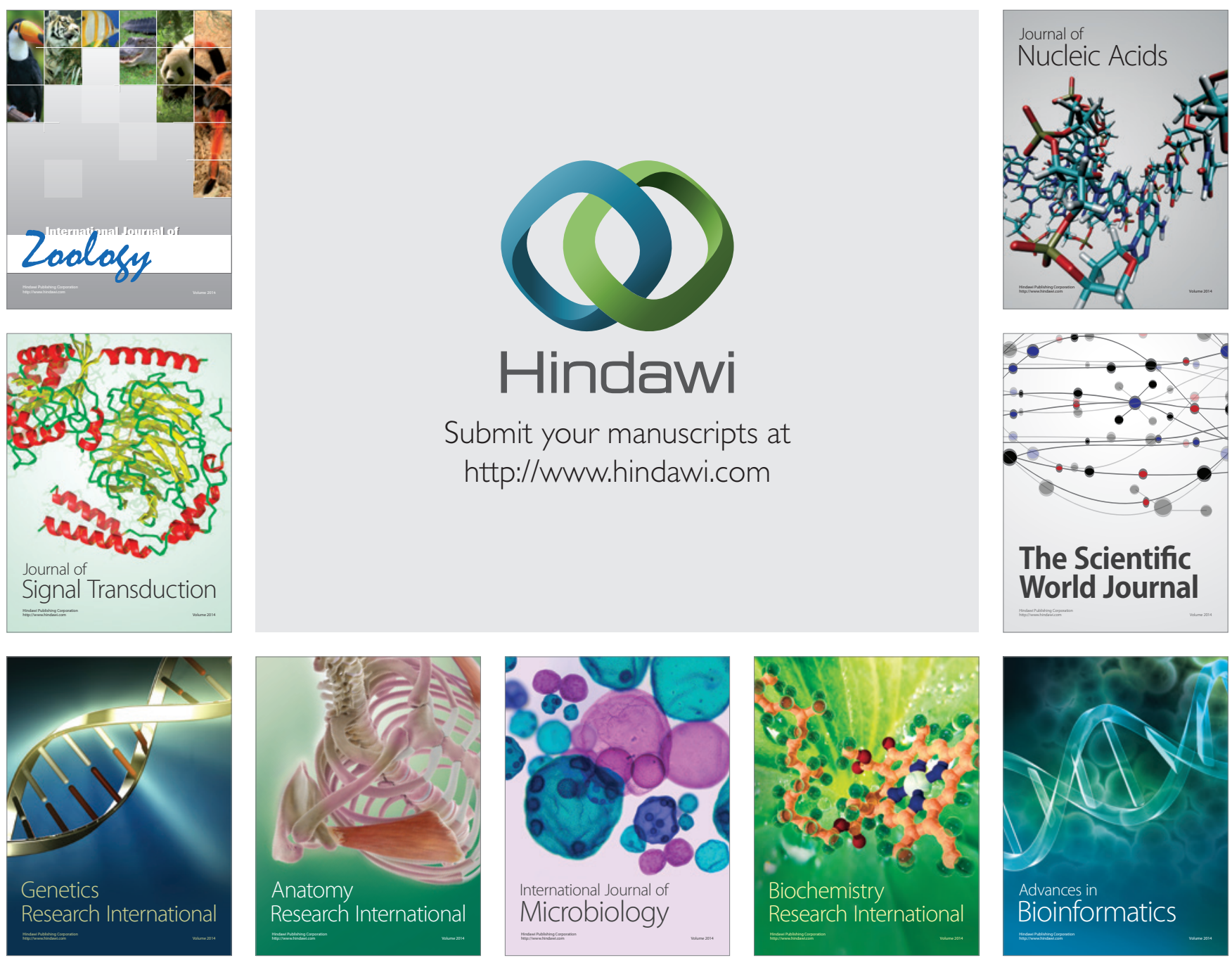

The Scientific World Journal
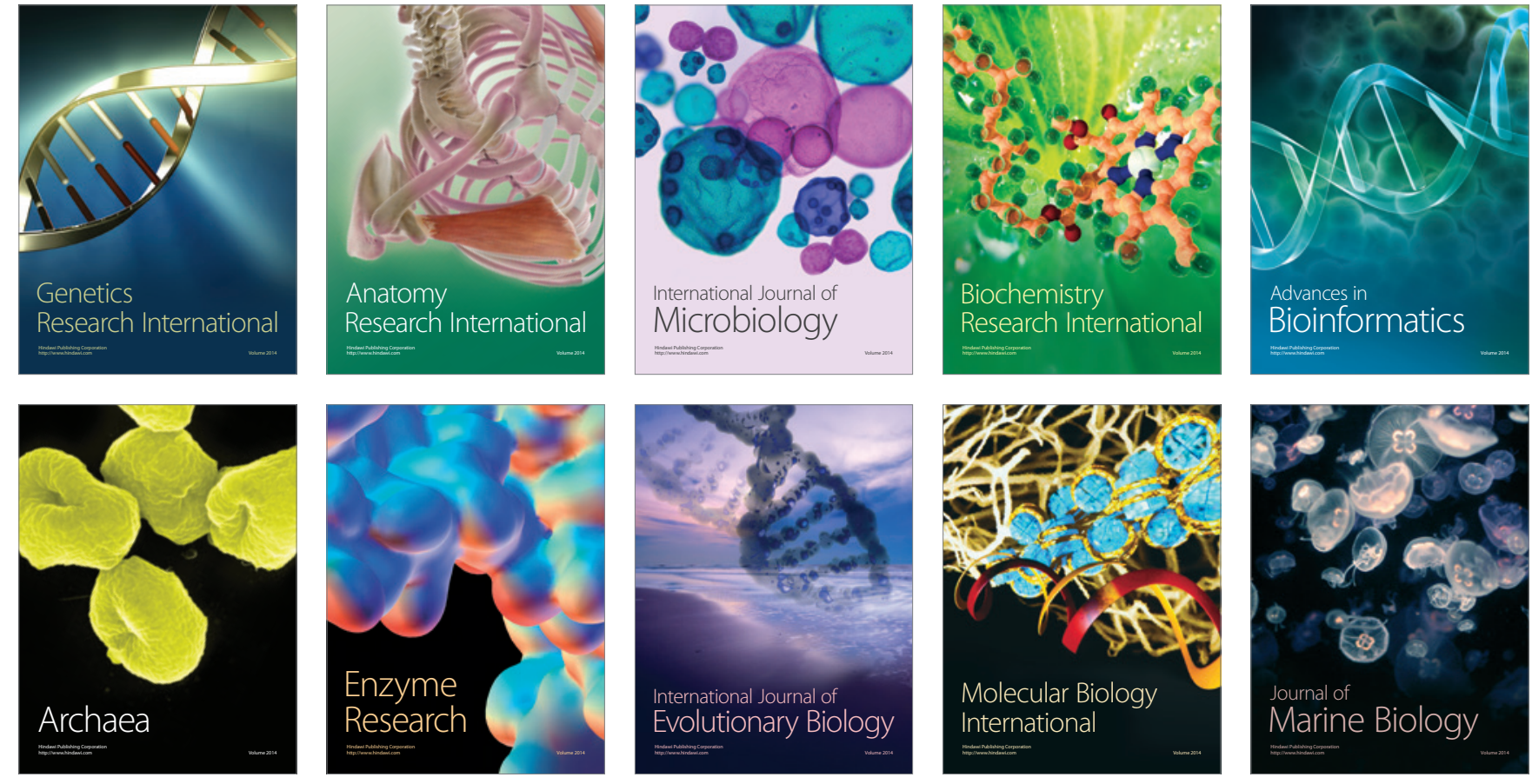